\title{
ACCOUNT OF THE BUSINESS MEETING, 24 MAY 1991
}

\section{WILLEM G. MOOK, CHAIRMAN}

1. Announcements were made by Erv Taylor, Austin Long and Renee Kra concerning publication of the Lake Arrowhead and Tucson Proceedings.

2. K. Rozanski briefly reviewed the situation regarding the IAEA ${ }^{14} \mathrm{C}$ Reference Materials. Full details on the intercomparison data are published in a report obtainable from:

Dr. K. Rozanski

Section of Isotope Hydrology

International Atomic Energy Agency

P. O. Box 100

A-1400 Vienna, Austria

3. The status of the calibration of the ${ }^{14} \mathrm{C}$ time scale, as discussed at a workshop in Groningen, 6-8 September 1989, attended by Becker, Damon, Kromer, Stuiver and Vogel, is briefly reviewed by Van der Plicht. Figure 1 shows the result.

4. ${ }^{14} \mathrm{C}$ Association. The chairman recollected discussions about a formal association that were held in Dubrovnik and his later circular letters to all laboratories. A concrete result has been that a number of colleagues who have no access to hard currency were furnished with subscriptions to and back issues of RADIOCARBON. The remaining money donated by nine laboratories covered travel expenses of some colleagues to this conference.

Despite the chairman neglecting Robert's Rules of Order, the meeting voted in favor of the installation of a committee, which will carefully proceed to prepare the foundation of an International $\mathrm{C}^{14}$ Association. Members of the committee were selected: Robert Hedges (UK), Austin Long (USA), Willem Mook (The Netherlands), Henry Polach (Australia), Jaan-Mati Punning (Estonia), John C. Vogel (South Africa) and Zhou Weijian (China). The Committee held its first meeting directly after the Business Meeting.

5. Future ${ }^{14} \mathrm{C}$ and $\mathrm{AMS}$ Conferences. A motion was presented "to hold coordinated and joint meetings on Radiocarbon and AMS every two years, with emphasis alternating on Radiocarbon and Cosmogenic Isotopes", starting with the AMS conference in 1993. After ample discussion, the vast majority voted against this resolution, and thus, in favor of continuing our Radiocarbon Conferences every three years, the next meeting to be in 1994.

6. Next ${ }^{14} \mathrm{C}$ Conference. After the conclusion of Item 7 on the agenda, a decision about the city to host the next conference was simple. Although it seemed originally that two laboratories were in the running, Groningen applied only for 1995, in case the previous motion was adopted. Glasgow then made a glorious presentation that was received very favorably, so that Glasgow will host the 15th International Radiocarbon Conference. Doug Harkness, Marian Scott and Gordon Cook will be the principal organizers.

7. Before final closure of the conference by Austin Long, the chairman thanked the Organizing Committee, RADIOCARBON and the University of Arizona Conference Service for hosting the 14C14. Tucson and the Westward Look Resort will be remembered dearly. 


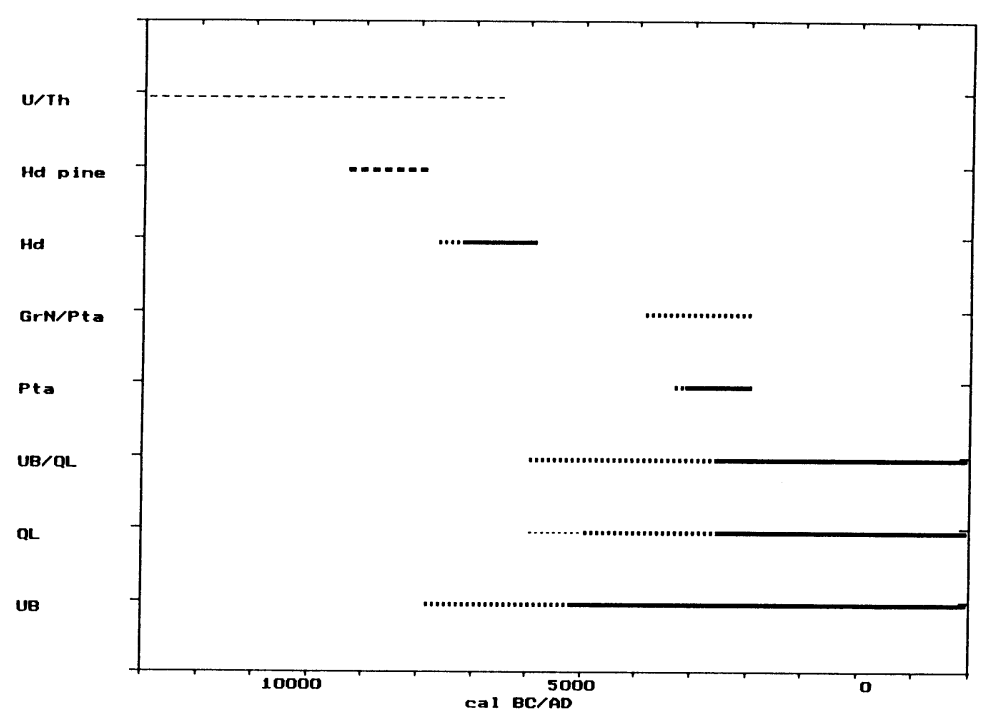

Fig. 1. UB-Belfast (20-yr curve)

QL (Seattle 10-yr curve)

UB/QL (combined 20-yr curve)

Pta (Pretoria 1 to 3 -yr curve)

$\mathrm{GrN} / \mathrm{Pta}$ (combined 1 to 3 -yr curve)

Hd (Heidelberg)

Hd pine

U/Th (Lamont-Doherty/Gif-sur-Yvette)

$$
\begin{aligned}
& -=\text { Trondheim } 1986 \\
& \text {...... = extension to } 7890 \mathrm{BC} \\
& \text { - }=\text { Trondheim } 1986 \\
& \text {...... = Lake Arrowhead } 1990 \\
& \text {...... = extension to } 6000 \mathrm{BC} \\
& -=\text { Trondheim } 1986 \\
& \text {...... = extension to } 6000 \mathrm{BC} \\
& -=\text { Trondheim } 1986 \\
& \text {...... = extension to } 3350 \mathrm{BC}
\end{aligned}
$$

$\mathrm{U} / \mathrm{Th}$ and ${ }^{14} \mathrm{C}$ dates of corals, calibration back to $30,000 \mathrm{BP}$ 